\title{
USE OF ADDITIVELY MANUFACTURED PATIENT-SPECIFIC INSTRUMENTS IN CLINICAL PRAXIS
}

\author{
UPORABA PACIENTU PRILAGOJENIH INSTRUMENTOV, \\ IZDELANIH Z DODAJALNO IZDELAVO, V KLINIČNI PRAKSI
}

\author{
Igor Drstvenšek ${ }^{1}$, Urška Kostevšek ${ }^{1}$, Tomaž Brajlih ${ }^{1}$, Nataša Ihan Hren ${ }^{2}$, Matjaž Merc ${ }^{3}$, \\ Tomaž Tomažičc ${ }^{4}$, Snežana Stevičč ${ }^{5}$ Matjaž Vogrin ${ }^{3}$, Andrej Moličnik ${ }^{3}$ \\ ${ }^{1}$ University of Maribor, Faculty of Mechanical Engineering, Smetanova ulica 17, 2000 Maribor, Slovenia \\ ${ }_{2}$ University of Ljubljana, Faculty of Medicine, Vrazov trg 2, 1000 Ljubljana, Slovenia \\ ${ }_{3}^{3}$ University Medical Centre Maribor, Ljubljanska ulica 5, 2000 Maribor, Slovenia \\ ${ }^{4}$ General Hospital Murska Sobota, Ulica dr. Vrbnjaka 6, 9000 Murska Sobota, Slovenia \\ ${ }^{5}$ University of Priština-Kosovska Mitrovica, Medical Faculty, Filipa Višnjiča bb, 38220 Kosovska Mitrovica, Serbia
}

Prejem rokopisa - received: 2018-07-15; sprejem za objavo - accepted for publication: 2018-10-18

doi:10.17222/mit.2018.152

Using a combination of Computer-Assisted Design (CAD), expert surgical knowledge and Additive-Manufacturing (AM) technologies, it is nowadays possible to offer patients an individualized treatment that is better planned, more predictable and more reliable than traditional surgical procedures. Regardless of the specifics of different medical fields, planning is common to all of them when it comes to an invasive intervention into the human body. Surgical planning is always based on diagnostic data that need to be gathered, presented and evaluated in a way that best suits the final purpose. To understand the general needs of the surgical planning process, several surgical cases have been explored and analyzed in the Additive Manufacturing Laboratory (AML) at the Faculty of Mechanical Engineering, University of Maribor over the past 10 years. The common denominator in all cases is the reconstruction of diagnostic data into a 3D model that is later used for planning and is, after the confirmation of the planned therapeutic parameters, transformed into tangible surgical equipment by means of AM. The 3D planning process has a lot of benefits but requires some skills uncommon among the medical experts. The results of the presented research summarize the particularities of medical 3D planning and provide guidelines for the wider adoption of medical 3D planning and the use of additively manufactured patient-specific instruments.

Keywords: additive manufacturing in medicine, 3D medical planning, surgical guides, patient-specific instruments and implants

Uporaba računalniško podprtega konstruiranja, specialističnih kirurških znanj in tehnologij dodajalne izdelave nudi pacientom individualno, bolje načrtovano, predvidljivejšo in zanesljivejšo obravnavo kot tradicionalna kirurgija. Natančno načrtovanje operacij je skupno vsem medicinskim področjem, kadar gre za invaziven poseg v človekovo telo, ne glede na medicinsko specializacijo. Načrtovanje kirurških posegov vedno temelji na diagnostičnih podatkih, ki jih morajo zajeti, predstaviti in ovrednotiti na način, ki ustreza končnemu cilju. Da bi razumeli splošne potrebe načrtovanja kirurških posegov, so v zadnjih 10 letih v Laboratoriju za dodajalno izdelavo Fakultete za strojništvo Univerze v Mariboru raziskali in analizirali precej kirurških primerov. Vsem primerom je skupna rekonstrukcija diagnostičnih podatkov v trirazsežne modele, ki jih kasneje uporabijo za načrtovanje, po potrditvi načrtovanih terapevtskih parametrov pa preoblikujejo $\mathrm{v}$ otipljiv kirurški pripomoček s pomočjo dodajalne izdelave. Proces trirazsežnega načrtovanja ima mnogo prednosti, zahteva pa nekaj znanj in spretnosti, ki med zdravniki niso običajne. Rezultati prikazanih raziskav povzemajo posebnosti trirazsežnega načrtovanja in podajajo smernice za bolj razširjeno uporabo pacientom prilagojenih medicinskih pripomočkov, narejenih s tehnologijami dodajalne izdelave.

Ključne besede: dodajalna izdelava v medicini, trirazsežno medicinsko načrtovanje, kirurška vodila, pacientu prilagojeni instrumenti in vsadki

\section{INTRODUCTION}

In recent decades, additive manufacturing (AM) has offered help in medical reconstruction and planning procedures to assist surgeons in re-establishing the functionality of injured or otherwise affected body parts in their patients. The first cases of AM-supported surgery in the Additive Manufacturing Laboratory (AML) at the Faculty of Mechanical Engineering, University of Maribor, covered the area of cranial and maxillofacial surgeries for which implants were custom-made for each patient. The first orthopaedic cases soon followed with bespoke resection guides that enabled the precise and

*Corresponding author e-mail:

igor.drstvensek@um.si faster replacement of shoulder, hip and knee joints. A similar technique has been used to manufacture patientspecific drill-guide templates that enabled optimal pedicle screw placement. The method has been evaluated by performing a clinical study involving the manufacture of templates for the lumbar and sacral regions that enabled simultaneous multiple-level screw implanting.

All the mentioned surgical cases come from different areas and have different motivations for interdisciplinary cooperation during their performance. Yet, they share a common source of planning data and an engineering approach independent of the particularities of the medical field. All 3D planning data used in such a process are gathered through a series of 3D imagings performed using one of the applicable techniques (MRI, X-ray CT, 
CBCT, USI). These data usually come in the form of DICOM that needs to be converted into $3 \mathrm{D}, \mathrm{CAD}$ data, suitable for further manipulation. The main problem of reliability is the accuracy of the gathered data, which is affected by the technique itself, the diagnosed body part and the operator or human factors at the time of imaging.

Defects in the craniofacial skeleton are of either congenital (birth defects), developmental orthognathic deformities) or accidental (resulting from trauma, infection, tumour, etc.) cause. The purpose of reconstructing abnormalities is primary functional. In cranial-maxillofacial treatments, implants need to fulfil an aesthetic function too. The possibilities for their prefabrication by means of serial production are very limited. Therefore, these implants and instruments are individually made using either subtractive (CNC milling) or additive (Laser sintering or melting) technologies. The production of such implants starts by reconstructing a three-dimensional data set of the problematic area (skull, mandibular area, pelvis, shoulder rim, etc.) from CT or MRI two-dimensional pictures. This reconstructed model is then used for modelling the missing bones. The digital model is then manufactured using either CNC milling (PEEK and ceramic - $\mathrm{ZrO}_{2}, \mathrm{AL}_{2} \mathrm{O}_{3}-$ implants) or Additive Manufacturing (metal implants and surgical instruments).

Besides producing a patient-specific implant, the 3D model reconstructed from diagnosing imagery can be effectively used for the preparation of the surgical treatment. This is especially important in cases where the functionality of the body part must be re-established. Such examples are orthopaedic surgeries where the functionality of the limbs after the surgical procedure depends on the positioning of the implant. Virtual models can be used to study the surgical procedures, like the directions of implantation, the required pre-operational treatments and the preparations, etc. Very interesting in this sense are total hip replacement (THR) operations that are, due to an ageing society and unhealthy lifestyles, constantly on the increase. Since the primary THRs are performed on ever-younger patients the number of revisions is constantly increasing too. ${ }^{1}$ Two-dimensional pre-operative planning, ${ }^{2,3}$ which is due to a simple process still in general use, has several disadvantages that often lead to longer surgical procedures, ${ }^{4}$ inaccurate positioning of the endoprosthesis, ${ }^{5}$ additional bone loss, ${ }^{6}$ limb length discrepancy, ${ }^{7}$ longer rehabilitation and increased overall costs. ${ }^{8,9}$

This observation also proved itself in a case of the use of pedicle screw systems for vertebral fusion. It is routinely used for stabilization between two or more spinal levels in degenerative, traumatic, oncogenic or pre-operatively deformed vertebrae. ${ }^{10}$ During pedicle screw insertion, it is important both to select the correct size of the screw and to place it properly within the pedicle to ensure good anchoring. The free-hand technique has a high associated rate of unplanned per- foration, which is the major specific complication of pedicle screw placement and causes a high risk of bone weakening or lesions of the spinal cord, nerve roots or blood vessels. ${ }^{11}$ Individualized drill-guide templates for the lumbar spine were first introduced in 1998. The recent study of the AML and University Clinical Centre in Maribor established that the use of a multi-level drill guide improves the accuracy of pedicle screw positioning in the lumbar and sacral spine, and that the application of multi-level drill guides is reasonable in screw placement on the first sacral level. ${ }^{12}$

\section{CLINICAL EXPERIENCES}

\subsection{Custom-made cranio-maxillofacial implants}

In the past 12 years, 31 cases of cranioplasty have been performed in a cooperation between the AML and three clinical institutions in Slovenia. One of the patients was treated with a titanium implant produced by SLM technology and all the others by the indirect approach in which the template of the cranial implant was additively manufactured and later used to produce a silicone rubber mould (SRM). A so-called bone cement, a mixture of PMMA and ceramic powder, was moulded in the SRMs to form a biocompatible implant.

The easiest way to reconstruct the structure of a patient's bones is to use those CT images that already exist from previous treatments of the patient. A set of CT images can be converted into a three-dimensional, digital model using one of the available software packages, such as: EBS (Ekliptik), Mimics (Materialise), 3D doctor (Able Software), Amira (Thermo Fisher Scientific), Dolphin 3D Surgery (Dolphin/Patterson Dental), 3D Slicer (Open Source) or others. ${ }^{13}$

The three-dimensional model can be further manipulated with several CAD software packages. The usual 3D modellers based on parametric, volumemodelling techniques are not very well suited to the task. Newer versions of these software packages (SolidWorks, Delcam, etc.) enable the manipulation of triangulated surface files, but using dedicated software, known from Reverse Engineering fields, such as Magics (Materialise), PolyWorks (InnovMetric), MeshLab (open source), MeshMixer (Autodesk) or others is much more effective in terms of time and effort. Using these tools the missing tissue can be modelled and saved as new files. These can be further processed or used to produce real implant models using one of the AM technologies. Reconstructed models of the skull and the implant have been manufactured using several different AM technologies.

In the case of skull implants Selective Laser Sintering (SLS), PolyJet ${ }^{\mathrm{TM}}$ and stereolithography (SLA) were used for the production of communication models and patterns for implant production. SLS technology builds parts from powder that is solidified in slices by a laser beam. The powder is one of the well-known plastic 
compounds (usually polyamide) stored in special containers beside the machine's working surface. From here it is applied by a "recoater" onto the working surface for each layer, separately. PolyJet technology builds models from photo polymeric resins. Each layer is jetted on the work tray by a printing head and then cured by ultraviolet light. The support material is later removed by a water jet. Stereolithography produces parts in a vat filled with a photopolymer resin. The resin is solidified by means of a UV laser that selectively scans the surface of the resin until the cross-section of a layer is solidified. The support structure is made of the same material as the part and needs to be manually removed after the process is finished.

SLS produces rigid and resistant polyamide parts with a relatively high surface roughness. The roughness makes the SLS parts unsuitable for silicone rubber moulding unless the parts undergo a surface treatment, usually vibration polishing. The PolyJet process produces smooth parts with lower rigidity at a higher price. On the other hand, the price difference in the case of smaller parts such as the implant for cranioplasty is not a substitute for PolyJet's better performance in terms of surface and dimensional quality. The parts produced with stereolithography have comparable mechanical properties to the PolyJet parts, a slightly smoother surface, but require a more demanding process for supporting structure removal.

For the direct production of implants either Selective Laser Melting (SLM) or Electron Beam Melting technology is used. Both can produce fully dense metal parts and both provide the environment for producing a biocompatible implant out of reactive metal alloys, such as titanium grade 23. Both technologies employ a powder-bed system with a recoater to deliver the material onto the building tray. The SLM technology uses a Yb-glass fibre laser and operates within a chamber filled with argon with less than $0.8 \%$ of remaining oxygen. The EBM technology operates in vacuum with a high-power electron beam (up to $4 \mathrm{~kW}$ ) that selectively melts the powdered material and binds it into the final product.

For the indirect production of biocompatible implants, a modified SRM procedure has been used. A SRM was made using a normal frame to hold the silicone and the pattern. ${ }^{14}$ The pattern holders were purposely made from 5-mm steel wires to make some room for the excess PMMA compound (Figure 1).

Since the material cannot be poured into the mould through a normal gating the material needs to be mixed in one half of the mould and then pressed together with the other half to achieve the final form. Therefore, the mould was equipped with guiding rods to prevent side movements and with some extra openings to release the excess amount of bone cement out of the mould during the pressing process. (Figure 1). The finished implants need to be sterilized by low-temperature sterilization to avoid changes in the polymeric structure of the PMMA.

The cranioplasty operations have traditionally been performed with no alterations to the standard procedure. The implant was inserted into the skull of the patient and fixed using titanium plates and screws. A CT inspection showed good position of the bone cover. The whole duration of the operation has been shortened by approximately $50 \%$, due to the preparation work (planning, fit and function testing, production of custom-made implant) carried out before the operation.

The 3D modelling of skull implants is a relatively simple task because of the typical shape that can be regenerated from the tissues adjacent to the defective area. Other areas of the head are more demanding because of the more complicated bone morphology. Such is the case of a 24-year-old mentally healthy man, born with hemifacial microsomia. This is a severe asymmetry of the facial bone and soft tissues in the vertical, sagittal and transverse plane combined with hearing impairment on the affected side. He was treated using classic orthognathic surgical procedures and by distraction osteogenesis of the mandible. After these surgical procedures the remaining defect of the bone and soft tissues was partially compensated by a custom-made titanium angular implant.

To find the optimal shape of the angular implant the skull's virtual model was split into two parts along the nose plane. The healthy side was mirrored across the nose plane and super-positioned over the left part of the face.

The Boolean subtraction between the mirrored and original skull part produced a reference model (Figure 2). The implant was modelled between the reference and
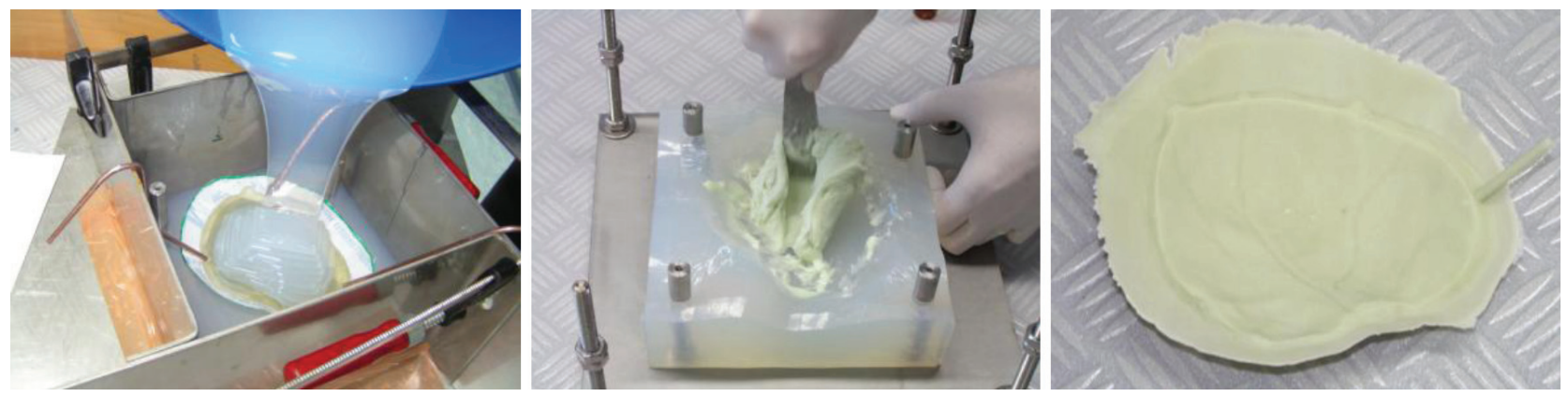

Figure 1: a) Manufacturing of SRM mould, b) moulding of implant, c) molded PMMA implant with excess material at the parting plane ${ }^{15}$ 

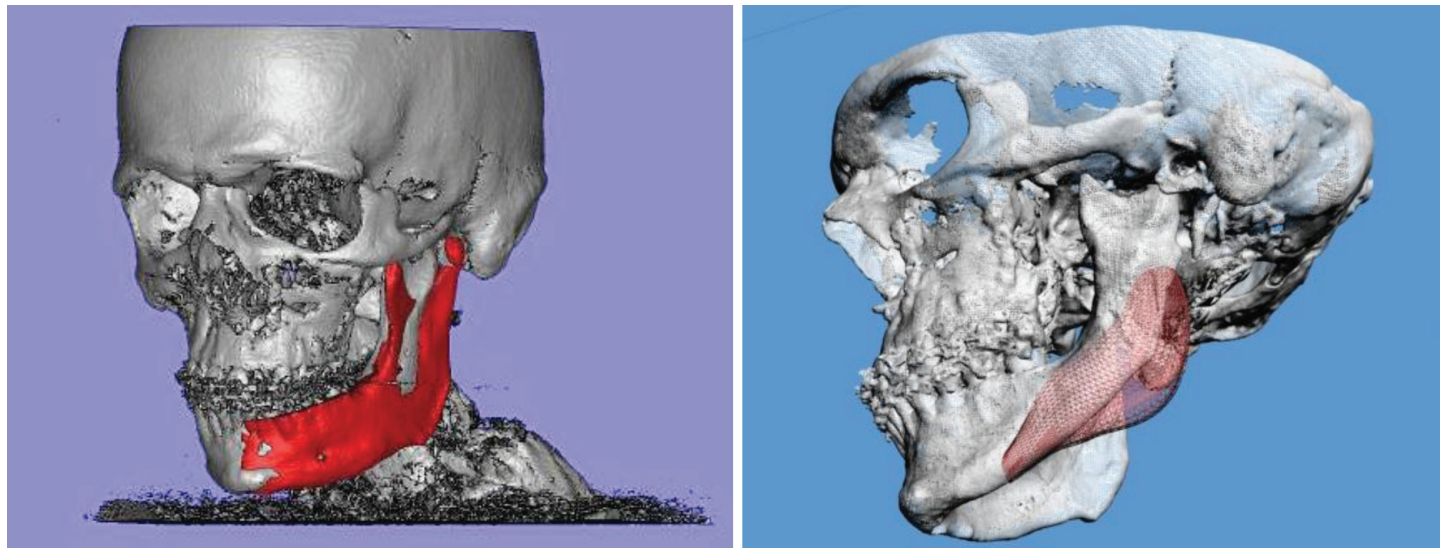

Figure 2: Reference shape for implant design and the final implant's shape $\mathrm{e}^{15}$

the original shape of the mandible. It had to be lightweight and easy to handle during the operation.

To evaluate the implant's shape models of the skull and the implant were created using the SLS technology. They enabled an effective communication between the medical doctor and the engineer (Figure 3). After the surgeon's evaluation of the models the implant's shape was slightly changed to accommodate the mandibular muscles. After confirming the final design, the implant was produced out of Ti-grade 23 alloy, using SLM technology.

\subsection{Orthopedic surgical planning}

In cases of orthopaedic surgery, the 3D planning and surgical preparation play a very important role. The implants in these cases come from serial production, but their implantation depends on the skills of the surgeon and on his/her planning possibilities. Conventional 2D pre-operative planning is performed on the anteroposterior (AP) pelvic radiography, which directly provides the data about the inclination angle and the centre of the hip's rotation. The version angle can only be calculated indirectly given that the lesser trochanter is visible in the radiograph and that its size can be reliably defined. This fact and the lack of reliable anatomical landmarks accessible during the surgery make 2D planning outdated and inappropriate for modern THA operations. ${ }^{16}$

Anatomical landmarks are intra-operational, easily accessible bone structures that are clearly visible on the radiographic images. These usually include the medullary canal (shaft), the greater and lesser trochanter, the acetabular roof, saddle and the teardrop (Figure $\mathbf{4 a}$ ). The problem of anatomical landmarks is that most of them are only visible on the radiographic images (some even because of overlapping bone structures), but most of them cannot be seen "in vivo" during the surgery.

Mechanical references are the distances between the different landmarks that define the functionality of the hip joint. After the THA operation, the hip movement must be restored into its anatomical state. This can only be ensured by a proper definition of the mechanical references, e.g., the original acetabular and femoral rotation centre, the femoral and acetabular offset and the leg length.

The measurements shown in Figure $\mathbf{4 b}$ are unreliable because they depend on the circumstances of the $2 \mathrm{D}$
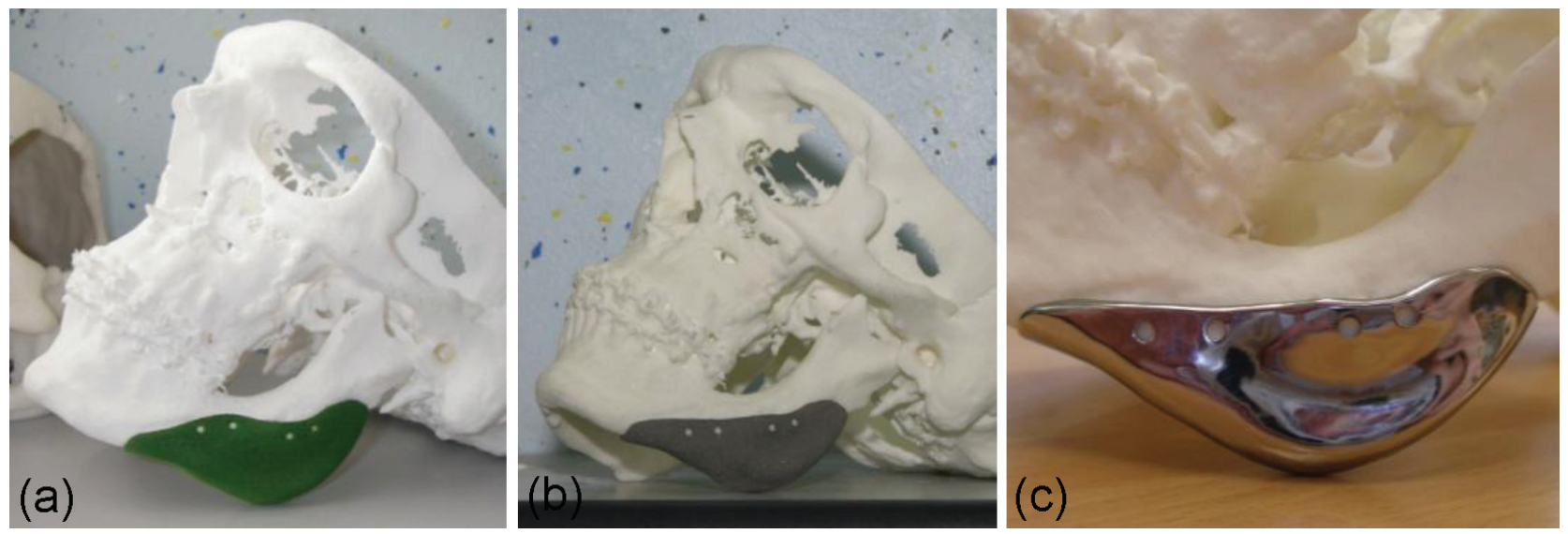

Figure 3: Angular implant: a) The model of the custom-made angular implant on the printed model of the patient's head skeleton, b) the Ti64 implant after SLM, c) the Ti64 implant after polishing ${ }^{15}$ 

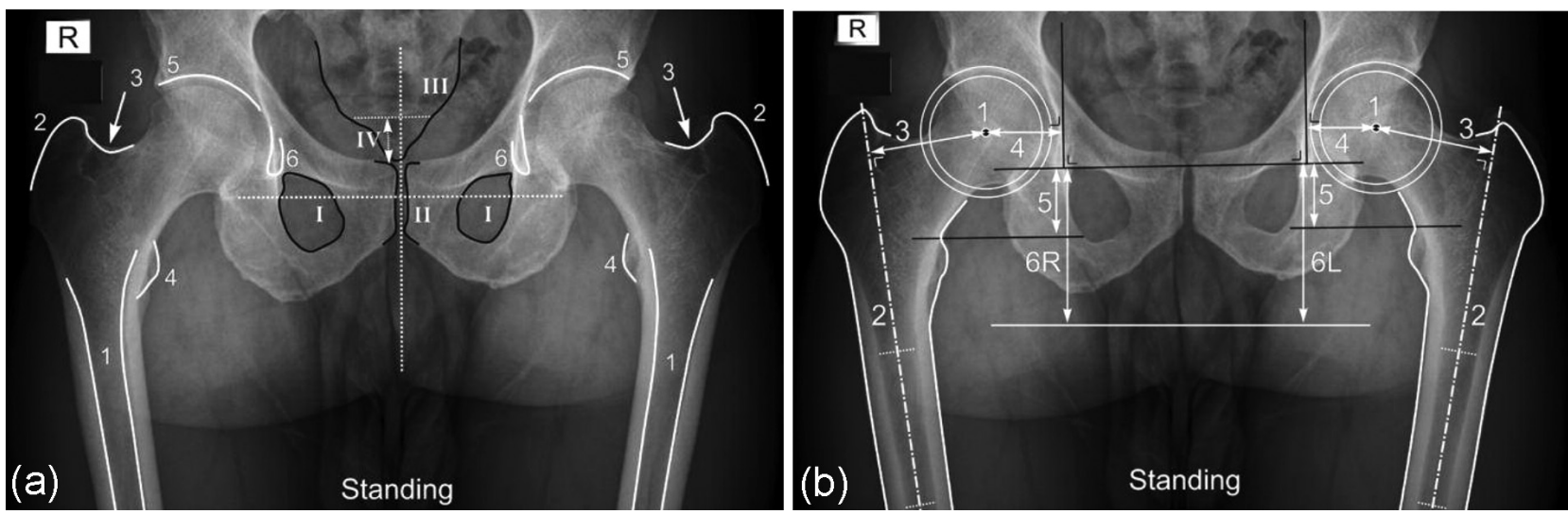

Figure 4: a) Anatomical landmarks: 1. Femoral shaft; 2. Greater trochanter; 3. "Saddle"; 4. Lesser trochanter; 5. Acetabular roof; and 6. Teardrop, b) Mechanical references: 1. Hip rotation centre; 2. Longitudinal axis of the proximal femur; 3. Femoral offset; 4. Acetabular offset; 5 . Hip length ("Leg length discrepancy" - distances between the $6 \mathrm{~L}$ and $6 \mathrm{R})^{16}$

radiograph's acquisition, its magnification factor and the influence of the version angles unidentifiable in the $2 \mathrm{D}$ plane of the radiograph. ${ }^{16}$ In a 3D space obtained from the CT, datasets all the references can be measured directly and their precision only depends on the accuracy of the CT scanner.

To overcome the obstacles of 2D surgical planning its benefits were combined with the possibilities of the 3D space. This is obtained by reconstructing the bone structures from the CT scans into 3D data. Prior to the 3D surgical planning process a coordinate system has to be defined, which corresponds to the established surgical practice. According to the proposition of Baauw M. et al. ${ }^{17}$ the Cartesian coordinate system of three planes (sagittal, coronal and transversal) was defined, using 3D landmarks found in the 3D model. The 3D planning consists of two phases. In the first phase the anatomical parameters of the hip joint are defined and in the second phase the devices to transfer the defined parameters into the patient's body are modelled.
The anatomical parameters are the version and inclination angles and the centre of rotation. In the 3D space they can be precisely defined using geometrical primitives and Boolean operators provided by the CAD software package. By placing the primitives into the virtual bone structure, the anatomical parameters of the hip can be measured with an accuracy and reliability not possible in the $2 \mathrm{D}$ planning process. Using Boolean operators the bone structure was subtracted from the pre-modelled, standard templates to model the custommade resection guides that can be produced by AM technologies. These resection guides were used during the surgery to help the surgeon maintain the calculated anatomic parameters in the operational space (Figure 6). A resection guide is an individual medical device made of polyamide (PA) and intended solely for interoperational use to transfer the references of the virtual coordinate system into the patient's body, thus facilitating the achievement of the planned parameters (CR, INC, AV).
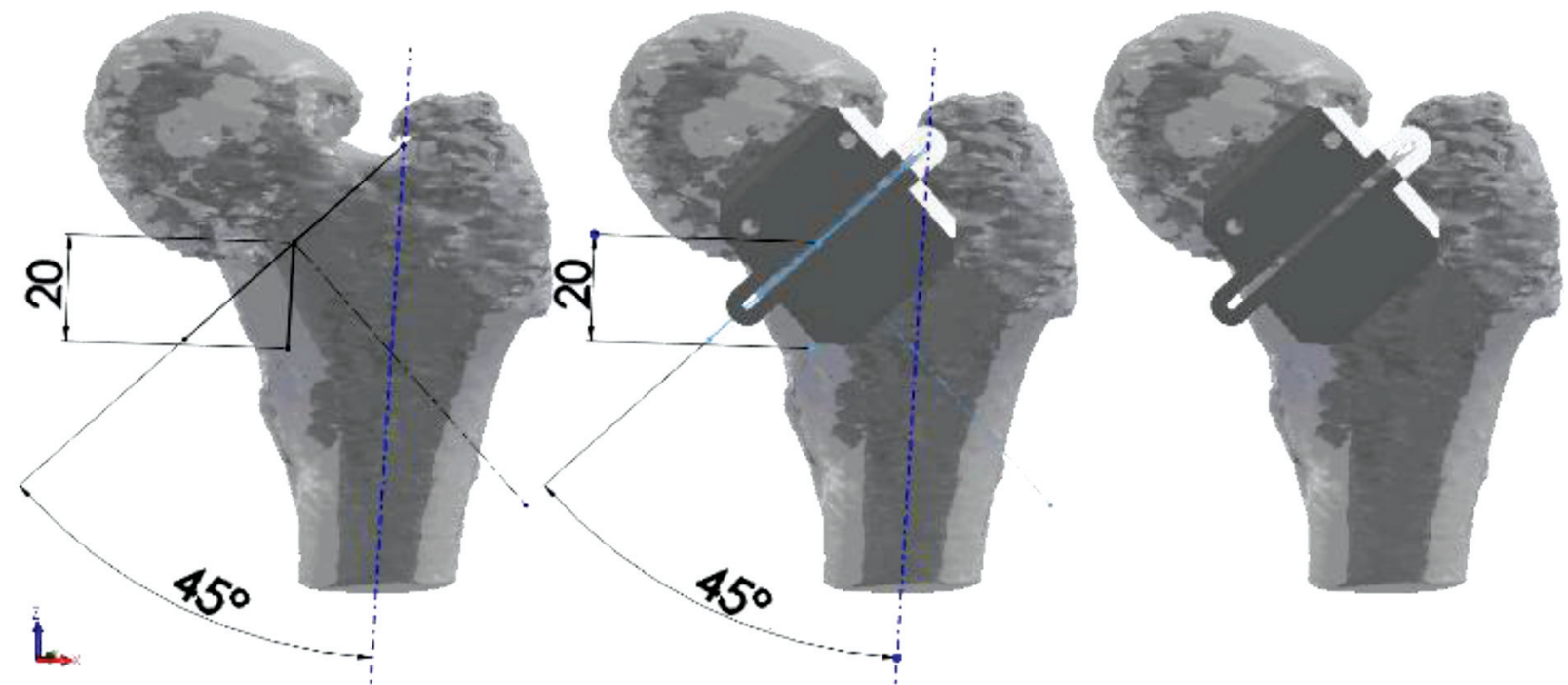

Figure 5: Individual medical devices for the femoral resection ${ }^{15}$ 


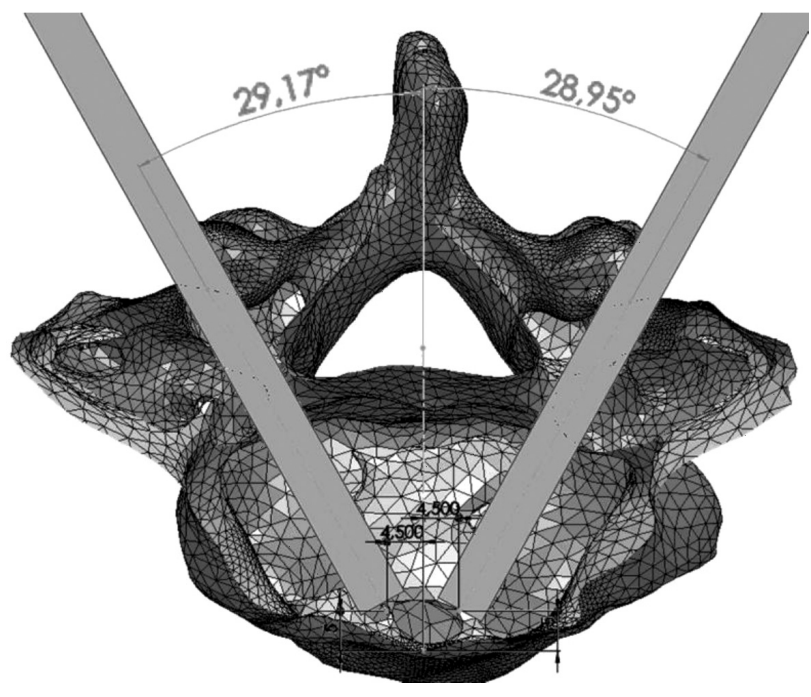

Figure 6: Determination of screws' direction. Screws are directed through the centre of the pedicle towards the midpoint of the ipsilateral half of the vertebral corpus. ${ }^{15}$

The described method has been clinically tested on five patients. Informed consent was obtained. All the patients suffered from primary osteoarthritis type IIA according to the Paprosky classification system. The post-operative CT analysis was performed to establish the quality of planned parameters transfer with the used resection guides.

\subsection{Drill-guide templates for positioning of pedicle screws}

Using a multi-level template for positioning the pedicular screws into multiple vertebrae levels strongly depends on the ability to put the spine into the same intravertebral positions as during the diagnostic imaging. To achieve this condition, a CT scan of the lumbar and sacral spine was performed on patients lying in the prone position to simulate similar facet joint relations as during the operating procedure. The images were transferred to a workstation running EBS ver. 2.2.1 (Ekliptik, Slovenia) software to generate a $3 \mathrm{D}$ reconstruction model for the targeted lumbar or sacral vertebra. The 3D spine model was used to determine the optimal screw size and orientation. The pedicle circumference and direction were investigated by pointing the virtual screw towards the centre of each half of the corpus vertebrae. Then, a $3 \mathrm{D}$ vertebral model was reconstructed with virtual screws placed on both sides and on different levels. The optimal screw length was also determined so that the end of the screw reached $50-80 \%$ of the vertebral diameter (Figure 6).

Using the achieved virtual screws, a drill-guide template was constructed with a surface designed to be the inverse of the dorsal part of the facet joint. That was meant to enable a lock-and-key mechanism fitting the dorsal part of the facet to achieve minimal overlap. The parts of the template for each pedicle screw were connected to each other in the sagittal and transversal plane to achieve the maximum stability of the template. (Figure 8). Additionally, cylinders fitting a trajectory hole were manufactured, allowing a temporary fixation of the drill guide with K-wires. The drill guide was produced with selective laser sintering technology from Polyamide 12.

The drill-guide templates were clinically tested in an open-label clinical trial on 20 subjects, featuring the implantation of 54 pedicle screws using drill-guide templates and 54 screws using the free-hand technique. Fluoroscopy surveillance was used in both groups.

All the patients underwent a postoperative CT scan that was used for the post-operative analysis of the screw placements.

\section{RESULTS}

The cranial and angular implants were the first trials that proved the usability of the CT scans for the accurate design and production of the medical implants. The main question in all cases was the reliability of the $3 \mathrm{D}$ data reconstructed from the CT scans. The trials showed that the achieved deviations fall within the dimensional field of $1 \mathrm{~mm}$ and the main contribution to the final deviations was in all cases added by the production process. ${ }^{18}$
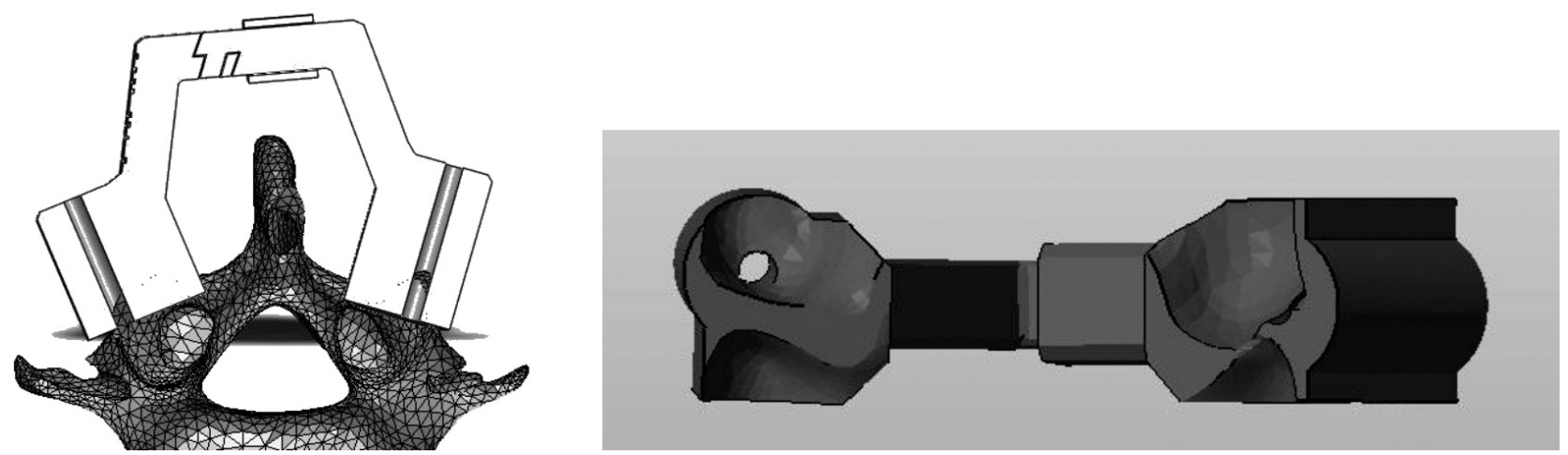

Figure 7: Design of a multi-level drill-guide template. A drill guide fits onto the dorsal elements of the facet joint. Parts of the guide are connected to each other to achieve better angular stability. ${ }^{15}$ 
The post-operative analysis of the positioned hip implants using the described method was performed by comparing the planned positioning parameters (INT, AV, COR) with the achieved position of the implant assessed from the post-operative CT scan. The results in Table 1 show that the largest deviation between the planned and actual position occurs in the coronal plane $(1.25 \mathrm{~mm})$. The absolute spatial difference is $1.40 \mathrm{~mm}$. The difference between the planned and the post-operative inclination of the femur is relatively large, as compared to the other orientation angles $\left(2.27^{\circ}\right)$. This is due to an unreliable definition of the femoral anteversion that can only be defined according to the direction of the condyles in the knee joint, which are not visible in the $\mathrm{CT}$ of the pelvis area. Therefore, the femoral anteversion was measured against the position of the pelvis.

Table 1: Data of planned and post-operative centres of rotation, angles of inclination and anteversion

\begin{tabular}{|c|c|c|c|}
\hline $\begin{array}{c}\text { Transversal } \\
\text { plane }\end{array}$ & Planned & Post-operative & Difference \\
\hline CR_FE & $95.82 \mathrm{~mm}$ & $95.77 \mathrm{~mm}$ & $0.05 \mathrm{~mm}$ \\
\hline CR_AC & $95.82 \mathrm{~mm}$ & $95.50 \mathrm{~mm}$ & $0.32 \mathrm{~mm}$ \\
\hline Sagittal plane & Planned & Post-operative & Difference \\
\hline CR_FE & $46.87 \mathrm{~mm}$ & $46.28 \mathrm{~mm}$ & $0.59 \mathrm{~mm}$ \\
\hline CR_AC & $46.87 \mathrm{~mm}$ & $46.32 \mathrm{~mm}$ & $0.55 \mathrm{~mm}$ \\
\hline Coronal plane & Planned & Post-operative & Difference \\
\hline CR_FE & $1.91 \mathrm{~mm}$ & $2.97 \mathrm{~mm}$ & $1.06 \mathrm{~mm}$ \\
\hline CR_AC & $1.91 \mathrm{~mm}$ & $3.16 \mathrm{~mm}$ & $1.25 \mathrm{~mm}$ \\
\hline Inclination & Planned & Post-operative & Difference \\
\hline INC_FE & $135^{\circ}$ & $132.73^{\circ}$ & $2.27^{\circ}$ \\
\hline INC_AC & $40.75^{\circ}$ & $41.53^{\circ}$ & $0.78^{\circ}$ \\
\hline Anteversion & Planned $^{\circ}$ & Post-operative & Difference \\
\hline AV_FE & $15.13^{\circ}$ & $13.98^{\circ}$ & $1.15^{\circ}$ \\
\hline AV_AC & $26.73^{\circ}$ & $24.77^{\circ}$ & $1.96^{\circ}$ \\
\hline
\end{tabular}

The usability and accuracy of the drilling templates for the pedicle screw placement were established in two ways. Firstly, the post-operative positions of the screws

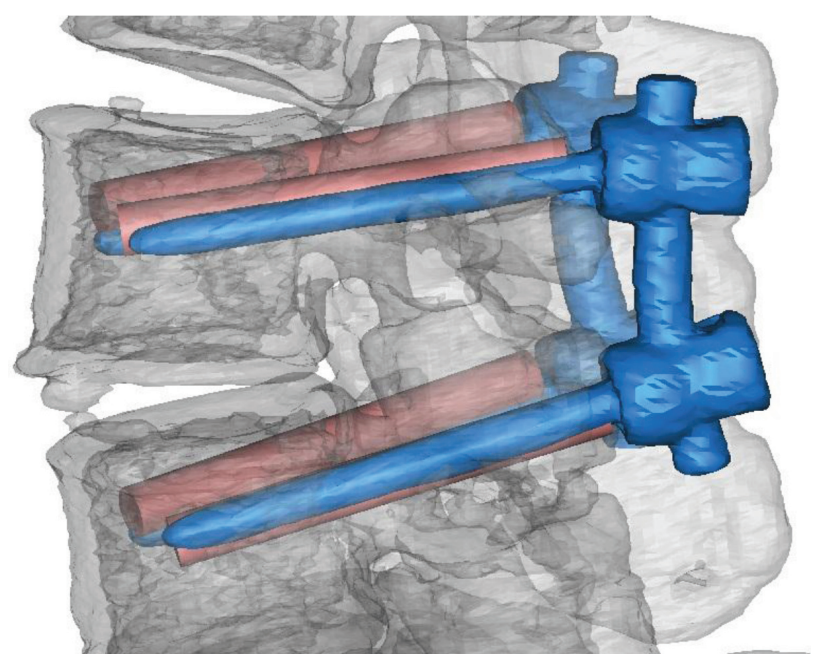

Figure 8: Comparison of the planned and the actual positions of the pedicle screws ${ }^{15}$ were compared to the planned positions by reconstructing the $3 \mathrm{D}$ models of the positioned screws from the post-operative CT scan and super-positioning them over the planned 3D models, as shown in Figure 8.

The comparison in most cases showed negligible deviations. A more insightful analysis was performed by comparing the screw accuracy and the pedicle cortex perforation (level of pedicle violation) between the control and the template group. The accuracy was measured using EBS ver. 2.2.1 (Ekliptik, Slovenia) software and defined as the eccentric position of the screw according to the smallest diameter of the ellipse of the pedicle.

In both groups 54 pedicle screws were inserted. The perforation of the pedicle cortex or the cortex of the corpus vertebrae was significantly lower in the drillguide group. The screws in the control group were displaced significantly more medially from the centre of the pedicle and directed more laterally from the optimal trajectory in the sagittal plane. There was no statistically important difference between the groups in the transversal plane, although the SD level in the control group was higher. The screw length violation occurred less frequently in the drill-guide group; but without the difference being significant (Table 2).

Table 2: Pedicle screw position measurements for lumbar and $1^{\text {st }}$ sacral level. SD standard deviation, ${ }^{a}$ Negative value means displacement/ deviation laterally, ${ }^{b}$ Negative value means displacement/deviation caudally, ${ }^{\mathrm{c}}$ The tip of the screw exceeds $50-80 \%$ of the corpus vertebrae diameter.

\begin{tabular}{|l|c|c|c|}
\hline & Drill guide & Control & $\mathrm{p}$-value \\
\hline \multicolumn{1}{|c|}{ No. of screws } & 54 & 54 & \\
\hline Perforation of cortex & 6 & 21 & $<0.001$ \\
\hline $\begin{array}{l}\text { Displacement sagittal } \\
(\mathrm{mm}), \text { mean (SD) }\end{array}$ & $0.3(3.4)$ & $1.5(3.2)$ & 0.05 \\
\hline $\begin{array}{l}\text { Deviation sagittal }\left(^{\circ}\right), \\
\text { mean (SD) }\end{array}$ & $-1(5)$ & $-6(8)$ & $<0.001$ \\
\hline $\begin{array}{l}\text { Displacement transversal } \\
(\mathrm{mm}), \text { mean }(\mathrm{SD})^{\mathrm{b}}\end{array}$ & $-0.7(1.5)$ & $-0.2(2.6)$ & 0.28 \\
\hline $\begin{array}{l}\text { Deviation transversal }\left({ }^{\circ}\right), \\
\text { mean (SD) }^{\mathrm{b}}\end{array}$ & $-1(5)$ & $0(11)$ & 0.71 \\
\hline Screw length violation $^{\mathrm{c}}$ & 14 & 20 & 0.21 \\
\hline
\end{tabular}

\section{DISCUSSION}

The presented results clearly show the usability and benefits of the 3D planning and the guided surgical principles. Benefits and tremendous time savings were observed when using custom-made cranial implants. In the cases of maxillofacial operations, the use of custommade implants shows the same potential, but the time savings are not so obvious, because of the more complicated surgical process. But in any case, the surgeon has a much better insight into the surgical procedure due to the $3 \mathrm{D}$ planning process and the communication models produced during the planning.

The benefits of 3D planning are even greater in orthopaedic surgical planning, because of the better 
possibilities to assess all the anatomical/geometrical data of the inspected body part. The results of the placement of five primary endoprostheses show that the deviations between the planned and achieved positions of the implants are almost negligible. This means that the planned, anatomical kinematics of the hip was re-established and gives a great deal of confidence that the endoprostheses will bear the planned stresses and survive the planned life-cycle.

The results of the use of the drill templates showed that a manufactured template significantly reduces the perforation risk of pedicle or vertebral corpus cortex in comparison with the free-hand technique under fluoroscopy supervision, which is more accurate than the classic free-hand technique. Due to the lower perforation risk, the probability of neural or vascular lesions was also reduced. ${ }^{11}$ When applying the template, the screw was more precisely centred in the pedicle, especially in the sagittal plane, resulting in a better stability of the screw and a higher pullout force of the screw. During the operating procedure, eliminating any tilting of the template was the most challenging part, especially in the transversal plane. This was minimized by the precise striping of the soft tissue lying next to the facet joints and applying moderate pressure to the template when fixing it and introducing a screw.

The same problem can be observed in THR operations, where the bones needed to be cleaned to provide reliable fitting between the bone and the resection guide. For this reason, the use of a resection guide requires the precise preparation of soft tissues next to the attaching areas and precise fitting and fixing of the guide. When this is achieved, a guide can be easily used, resulting in sufficient accuracy.

In cases of resection guides for orthopaedic surgery and drill guides for the pedicle screw placement, the accuracy of the overall process plays an important role. Again, it was established that the overall process with final plastic (either PA12 or photocured acrylic plastic) parts ensures the required accuracy for the clinical use of the guides.

\section{CONCLUSIONS}

The presented cases show that the use of modern technologies combined with interdisciplinary cooperation improves the overall effectiveness of surgeons, shortens the procedures, and lowers the risks and costs of the health-insurance system, providing more accurate and reliable planning and surgical processes.

The 3D reconstruction of bone tissues from the CT scanning data, and 3D pre-operational planning, make the surgical process more accurate and more reliable, but require better preparation of the referencing tissues. The accuracy of positioning the instrument is ensured by patient-specific templates designed to fit perfectly to the morphology of the patient's bones. In cases where only the implant is custom made for the patient and the implantation method remains unaltered, the surgical process can be significantly shorter, compared to serially made implants, mainly due to the pre-operational planning and the perfect fit of the implants. The use of patient-specific instruments such as drilling or resection guides requires an alteration to the standard surgical process. This involves the better preparation of hard tissues, the introduction of new, patient-specific instruments and the adaptation of the operating field to them. The introduction of Additive Manufacturing and 3D planning into the surgical process requires the introduction of engineering personnel into the surgical team, which needs to be foreseen in the organizational scheme of the institution. All these represent obstacles to a wider adoption of new technologies in medical/surgical fields and keeps these kinds of approaches at the level of pilot projects. Nevertheless, the presented results show that AM has huge potential in medicine, mainly due to its particularities that are in line with the requirements of additive technologies, e.g., one-off production, complicated shapes, rapid development, etc.

\section{Acknowledgement}

Parts of the present research were financially supported by the Slovenian Research Agency (research core funding no. P2-0157). The authors would like to thank the Department of Radiology in UCC Maribor, Slovenia, for assistance with the CT data scanning and data preparation.

\section{REFERENCES}

${ }^{1}$ V. Levašič, V. Pišot, I. Milošev, Arthroplasty Register of the Valdoltra Orthopaedic Hospital and implant retrieval program, Zdrav. Vestn., 78 (2009), 73-80, doi:10.6016/451

${ }^{2}$ A. Huppertz, S. Radmer, M. Wagner, T. Roessler, B. Hamm, M. Sparmann M, Computed tomography for preoperative planning in total hip arthroplasty: what radiologists need to know, Skeletal Radiol., 43 (2014) 1041-1051, doi:10.1007/s00256-014-1853-2

${ }^{3}$ C. Zeng, W. Xing, Z. Wud, H. Huang, W. Huang W, A combination of three-dimensional printing and computer-assisted virtual surgical procedure for preoperative planning of acetabular fracture reduction, Injury., 47 (2016), 2223-2227. doi:10.1016/j.injury.2016.03.015

${ }^{4}$ H. R. Blackley, Planning and management of the difficult primary hip replacement: preoperative planning and technical considerations, Instr Course Lect, 49 (2000), 3-11

${ }^{5}$ J. P. McAuley, Preoperative planning to prevent dislocation of the hip, Orthop Clin North Am, 32 (2001), 579-586, doi:10.5435/ 00124635-200511000-00005

${ }^{6}$ F. S. Haddad, Femoral bone loss in total hip arthroplasty: classification and preoperative planning, Instr Course Lect., 49 (2000), 83-96, doi:10.2106/00004623-199910000-00013

${ }^{7}$ K. T. Suh, Comparison of preoperative templating with postoperative assessment in cementless total hip arthroplasty, Acta Orthop Scand.,75 (2004), 40-44, doi:10.1080/00016470410001708070

${ }^{8} \mathrm{O}$. Cech, Preoperative planning and surgical technic in achieving stability and leg length equality in total hip joint arthroplasty, Acta Chir Orthop Traumatol Cech, 69 (2002) 362-8 


\section{DRSTVENŠEK et al.: USE OF ADDITIVELY MANUFACTURED PATIENT-SPECIFIC INSTRUMENTS IN CLINICAL PRAXIS}

${ }^{9}$ WM. Goldstein, Leg length inequality in total hip arthroplasty, Orthopedics, 28 (2005) 9, 336-341, doi:10.1007/s12178-013-9180-0

${ }^{10}$ T. A. Mattei, M. S. Meneses, J. B. Milano, R. Ramina, "Freehand" technique for thoracolumbar pedicle screw instrumentation: critical appraisal of current "state-of-art", Neurol India, 57 (2009) 6 , 715-721, doi:10.4172/2165-7939.S6-006

${ }^{11}$ S. C. Zeiller, J. Lee, M. Lim, A. R. Vaccaro, Posterior thoracic segmental pedicle screw instrumentation: evolving methods of safe and effective placement, Neurol India, 53 (2005), 458-465

${ }^{12}$ M. Merc, I. Drstvenšek, M. Vogrin, T. Brajlih, G. Rečnik, A multi-level rapid prototyping drill guide template reduces the perforation risk of pedicle screw placement in the lumbar and sacral spine, Archives of orthopaedic and trauma surgery, 133 (2013) 7, 893-899, doi:10.1007/s00402-013-1755-0

${ }^{13}$ T. Wohlers, Wohlers Report, Fort Collins, 2018

${ }^{14}$ H. Rotaru, M. Baciut, H. Stan, S. Bran, H. Chezan, A. Iosif, M. Tomescu, SG. Kim, A. Rotaru, G. Baciut, Silicone rubber mould cast poly-ethyl-methacrylate-hydroxyapatite plate used for repairing a large skull defect, J Craniomaxillofac Surg, 34 (2006) 4, 242-246, doi:10.1016/j.jcms.2006.01.005

${ }^{15}$ Courtesy of Additive Manufacturing Laboratory, Faculty of Mechanical Engineering, University of Maribor

${ }^{16}$ T. Scheerlinck, Primary hip arthroplasty templating on standard radiographs A stepwise approach, Acta Orthop. Belg., 76 (2010), 432-442

${ }^{17}$ M. Baauw, G. G. van Hellemondt, L. M. van Hooff, M. Spruit, The accuracy of positioning of a custommade implant within a large acetabular defect at revision arthroplasty of the hip, Bone Joint J., 97-B (2015) 6, 780-785, doi:10.1302/0301-620X.97B6.35129

${ }^{18}$ I. Drstvenšek, N. Ihan Hren, T. Strojnik, T. Brajlih, B. Valentan, V. Pogačar, T. Zupančič Hartner, Applications of rapid prototyping in cranio-maxilofacial surgery procedures, International journal of biology and biomedical engineering, 2 (2009) 1, 29-38 